\title{
Heavy Metals Toxicity in Agricultural Soils - Critical Review of Possible Sources, Influence on Soil Health and Remedial Measures to Remove, Reduce and Stabilize Contaminants in Soil
}

\author{
Dimple Kaparwan $^{1 *}$, N. S. Rana ${ }^{1}$ and B. P. Dhyani ${ }^{2}$ \\ ${ }^{1}$ Department of Agronomy, ${ }^{2}$ Department of Soil Science, Sardar Vallabh bhai Patel University \\ of Agriculture \& Technology, Meerut 250110, U.P., India \\ *Corresponding author
}

\section{Keywords}

Heavy metals, sources, Soil health, Remediation techniques, Phytoremediation, Immobilization, Soil washing

Article Info

\section{Accepted:} 18 May 2020 Available Online: 10 June 2020

\section{A B S T R A C T}

In today's scenario, heavy metal pollution has become one of the global problems to be dealt with, owing to rapid industrial growth, intensive agriculture and high population rate. The major challenge lies in feeding the overly populated country which creates more dependency on the use of fertilizers, pesticides, fungicides, and manures etc., to increase the crop yields. Use of agro chemicals coupled with waste water irrigation has resulted in rapid deterioration of soil quality due to over accumulation of heavy metals which are non degradable and persist for longer time in soils. Soil pollution by heavy metals is a significant environmental problem worldwide. Concentration of these heavy metals in soil has increased drastically over the last three decades, posing high risk to the environment and human health. Not only does a metal contaminated soil have a negative effect on plant growth and yield but it also poses severe threat to bioaccumulation of toxic metals in food chain and soil biological activity. Remediation methods used for heavy metal soil cleanup include physical, chemical and biological or a combination of these techniques to remove/ reduce/stabilize heavy metals in soil. Hence, cleanup of heavy metal contaminated soils is of prime concern and different techniques like immobilization, soil washing and bioremediation are known to be the best technologies for removing the contaminants in soils of most developed countries. Most recent step towards reduction of metal pollution in soils is the use of organic amendments and adoption of phytoremediation techniques which are cost effective, environment friendly and improve soil health. Use of organic amendments like farmyard manure, biochar, vermicompost and inorganic materials like lime, zeolites, iron oxides etc., reduce the metal mobility and bioavailability in soils. A combination of two or more of these soil amendments can be used to increase the efficiency of remediation process. This review paper presents possible sources of heavy metal pollution, their effect on soil health with appropriate remedial measures described in length. 


\section{Introduction}

After having achieved green revolution with indefinite use of agro- chemicals, farm mechanization and high yielding varieties, now the government is giving greater emphasis on quality of food in view of public health, due to greater risk involved by ingestion of food stuff contaminated with heavy metals (Khan et al.,2007). Remediation of heavy metal contaminated soils has emerged out to be a major challenge attributed to ever increasing population and huge industrial growth. The heavy metals may be geogenic or anthropogenic in origin, however, former accounts for the trace concentrations while later is hugely responsible for increased spread of heavy metals in environment. Different sources of heavy metal pollution such as agricultural and mining activities, industrial and municipal waste, leaded gasoline and paints, coal combustion residues etc., pose serious threat to human health and safety of ecosystem. Agricultural soils may become contaminated by the accumulation of heavy metals and metalloids through application of fertilizers, animal manures, sewage sludge, pesticides and wastewater irrigation etc., (Zhang et al., 2010). Unlike, organic waste which is oxidized to carbon oxide by microorganisms, most metals do not undergo bio- chemical degradation and remain in soils for a longer period of time. Organisms could be exposed to small amounts of heavy metals through water, air, food, and other commercially available products. The most common and toxic heavy metals include arsenic, cadmium, mercury, chromium and lead etc. Due to high mobility of cadmium especially in soils with low $\mathrm{CEC}$ and acidic $\mathrm{pH}$, it is considered as most phytotoxic metal pollutants which easily bioaccumulate in lower organisms and is being transferred to other trophic levels in the food chain (Lin and Aarts, 2012). Also, greater concentrations of heavy metals bear significant influence on the microorganism's population and their activity in the soil. Several research studies have revealed that higher concentration of heavy metals in soil causes shift in microbial populations (Gingell et al., 1976). The contamination of soils due to heavy metals is of great concern for human health due to direct ingestion of food crops grown on contaminated soils (McLaughlin et al., 2000, Ling et al., 2007). Because of its environmental significance, many studies to determine risk caused by metal levels in soil on human health and forest ecosystem have attracted attention in recent years (Krzyztof et $a l .$, 2004). However, heavy metal pollution of soil is an irreversible process and it is hard to manage and reclaim these kinds of metal polluted soils. Different methods to remediate heavy metal soils have been described viz., Physical, chemical, biological or their combination, with limited use of physical methods due to small area applicability and higher costs involved. Different chemical and biological methods of remediation like immobilization, soil washing, electro kinetics and bioremediation techniques are being used frequently for remediation of heavy metalcontaminated sites (Kirpichtchikova et al., 2006).

\section{Definition of heavy metals}

According to Nriagu and Pacyna (1988), heavy metals is a term given to collective group of metals and metalloids with atomic density greater than $5 \mathrm{~g} \mathrm{~cm}^{-3}$, or 5 times or more, greater than water. These are known to be toxic and poisonous even at low concentrations. According to EPA (2001) Arsenic, Lead, Mercury and Cadmium were placed at $1^{\text {st }}, 2^{\text {nd }}, 3^{\text {rd }}$ and $7^{\text {th }}$ position in top twenty hazardous substances list. Naturally, heavy metals exist in earth's crust and they can neither be degraded nor destroyed but could be transformed to less toxic forms. 


\section{Sources of heavy metals}

Parent material weathering, volcanic eruptions, forest fires etc., are the natural sources of heavy metals. The parent material has a greater impact on the heavy metal concentrations in different soils, with levels sometimes exceeding the permissible limits (Palumbo et al., 2000). During weathering process, the metals are either adsorbed in the topsoil or washed away to surface or groundwater resources. Trace amounts of $\mathrm{Ni}$, $\mathrm{Cr}$ and $\mathrm{Mn}$ are contained in some rock types of volcanic eruptions (Alloway, 1995). However, with the increased human activity the accumulation of heavy metals in soils has been accelerated resulting in possible threat to soil, plants, animal and human health (D'Amore et al., 2005). The major source of heavy metals in agricultural soils is the disposal of toxic metal untreated wastes, use of fertilizers, pesticides, manures, sewagesludge, compost and waste water irrigation etc., (Basta et al., 2005, Khan et al., 2008) that are discussed hereunder.

\section{Fertilizers}

Fertilizers act as a ready source of nutrients for adequate growth and development of plants. In intensive agriculture, continued soil application of large quantities of inorganic fertilizers result in accumulation of heavy metals (Khan et al., 2008) and thereby leads to deterioration of physio-chemical and biological properties of soil. For instance, phosphate fertilizers add heavy metals like cadmium, lead, arsenic, mercury and other potentially toxic elements to the soil which are considered as carcinogenic in nature (Pierzynski et al., 2000). Moreover, cadmium tends to accumulate in vegetables more than any other heavy metals and therefore it can easily enter food chain by direct intake of such metal contaminated vegetables.

\section{Pesticides}

Pesticide is a collective term given to insecticides, fungicides, herbicides, nematicides, rodenticides, molluscicides and plant growth regulators etc., with maximum consumption of insecticides in total pesticide share in India. Approximately $20 \%$ of the pesticide spray goes waste as run off in the soil which either leaches down and finds its way into the ground and surface water or vaporizes with the soil water (McLaughlin et al., 2000). These pesticides have proved harmful and detrimental to soil biological activity. Individual exposure to pesticides may cause various types of cancers, kidney damage and disrupt the functioning of thyroid glands (Khan et al., 2008). The first ever incidence of pesticide poisoning was reported from Kerala in 1958, in which more than 100 people died after consumption of wheat flour contaminated with parathion (Karunakaran, 1958).

\section{Waste water irrigation}

In India, approximately $1.0-1.5$ Mha area is irrigated with the use of waste water per annum (Sengupta 2008). A study conducted in various cities of Asian countries suggested that approximately, 50 percent of vegetable production in cities, is based on waste water irrigation (Acar and Akram, 1993). Since farmers are more interested in profitability, they prefer utilizing waste water instead of fresh water without know-how of its potential hazards to the environment. Long-term application of waste water in soils can eventually lead to heavy metal accumulation in soil. In a research trial to assess the effect of heavy metals $(\mathrm{Cd}, \mathrm{Cu}, \mathrm{Pb}, \mathrm{Zn}, \mathrm{Ni}$ and $\mathrm{Cr}$ ) on human health through intake of locally grown vegetables \& cereal crops irrigated with waste water by Singh et al., (2010) revealed that $\mathrm{Cd}, \mathrm{Pb}$ and $\mathrm{Ni}$ concentration were above the permissible limits of Indian 
and WHO/FAO standards in all the vegetables and cereal crops. The excessive accumulation of heavy metals in agricultural soils through waste water irrigation, may not only result in soil contamination, but also lead to elevated heavy metal uptake by crops, and thus affect food quality and safety. This loading of heavy metals often leads to degradation of soil health and contamination of food chain mainly through the vegetables grown in such soils (Rattan et al., 2002).

\section{Manures}

Incorporation of organic manures in the soils not only increases the nutrient status but also enhances the activity of microbial population. Though, organic manures are beneficial for soil health but they are also considered as a potential source of various heavy metals such as chromium, lead, arsenic, copper, cadmium, nickel, zinc etc., which accumulate in soil due to their continued application over time. For example, copper and zinc are added to the poultry and pig diet to boost up their growth and many of their health products contain toxic heavy metals like arsenic. The repeated soil application of manure produced from such poultry and animals which contain high concentrations of arsenic, copper and zinc poses serious threat to soil health with considerable build-up of these metals in the soil (Chaney et al., 1996).

\section{Disposal of untreated Sewage sludge}

Sewage sludge is composed of high amounts of organic matter, nitrogen, phosphorus and other compounds which are essential for plant growth and development. An estimated 62,000 million litres per day (MLD) sewage is generated in urban areas, while the treatment capacity across India is only 23,277 MLD, or $37 \%$ of sewage generated, according to data released by the GOI, December 2015. However, due to no operation and low maintenance of treatment plants less than 18,883 MLD of sewage is actually treated which accounts for $70 \%$ of sewage left untreated and is dumped as is in water bodies viz., rivers, seas, lakes and wells etc. Moreover, land application of solid sludge to improve soil fertility and sewage water for irrigation purpose has become a common practice in many developing nations (Hashimoto et al., 2009). However, sewage sludge also contain considerable amounts of heavy metals, including those which are identified as toxic, i.e., $\mathrm{Pb}, \mathrm{Ni}, \mathrm{Cd}, \mathrm{Cr}, \mathrm{Cu}, \mathrm{Hg}$ and $\mathrm{Zn}$. Though untreated sewage is being used by farmers to grow crops in sub-urban areas due to its high nutrient content, however, it's use for longer periods is a matter of great concern (Saha et al., 2010). The most common source of heavy metals in sewage sludge is domestic wastewater, surface runoff from urban area and corrosion of sewage system (Zhaoand et al., 2002). Use of such wastes in soils has resulted in significant build-up of heavy metals in agricultural land near several cities and towns of India (Saha and Panwar 2013).

\section{Industrial wastes}

With rapid rate of industrial growth, different waste materials are discharged from industries into sewage which leads to environmental pollution. Apart from domestic sewage, about 13468 MLD of wastewater is generated by industries of which only $60 \%$ is treated (Kaur et al., 2012). The existing treatment capacity is also not effectively utilized due to no operation and maintenance problems. Irrigation of crops with industrial waste water is a more common practice in developing countries. Worldwide, approximately, 20 million hectares of arable land is irrigated with waste water. Waste water irrigation over a period of time tends to develop problem of metal accumulation in soils, which poses serious threat of metal translocation from soil 
to crops. Though, incorporation of some industrial waste materials in soil has beneficial effect on agriculture or forestry but this also adds many hazardous heavy metals like chromium, lead, zinc and other toxic organic compounds to the soils.

\section{Effect of heavy metals on soil health}

Soil and water resources have been the major endpoints for heavy metal disposal and other waste materials released by various anthropogenic activities. Increased industrial and mining activities, surplus use of agro chemicals coupled with wastewater irrigation etc., has led to accumulation of heavy metals in soils. Since heavy metals cannot undergo microbial or chemical degradation, they remain for much longer period, once released in the environment (Lepp, 2012). The mobility of heavy metals in soil depends upon the availability of chemical form of the metal. The distribution of metals is assumed to be controlled by various chemical reactions of heavy metals in soils viz., precipitation, ion exchange, adsorption, complexation, immobilization and plant uptake. Contamination of soil with heavy metals not only alter soil $\mathrm{pH}$, porosity, colour and its biological properties but also impact the ground and surface water resulting in overall deterioration of soil and water quality (Musilova et al., 2016). There are few heavy metals viz., $\mathrm{Cu}, \mathrm{Fe}, \mathrm{Mn}, \mathrm{Si}, \mathrm{Mo}, \mathrm{Co}, \mathrm{Se}$ and $\mathrm{Zn}$, which are essential for plant metabolic activities. However, when present in higher concentrations, excessive metals could be transferred from soil to plants, ultimately opening heavy metal pathway for human exposure. The main source of heavy metal entry in agricultural soils is due to usage of fertilizers, pesticides, organic manures, application of urban and industrial wastes in fields, irrigation using wastewater and atmospheric pollution from motor vehicles etc., (Nicholson et al., 2003; Zhang, 2006).
Mostly, pesticides contain heavy metals which become available in considerable amounts in the soils. Moreover, application of phosphate fertilizers also contaminates the soil with arsenic, cadmium, lead, manganese and zinc. Soil incorporation of manures which are produced from chicken and pig, fed with special diet products introduce $\mathrm{Zn}$, As and $\mathrm{Cu}$ in soils (Mirsal, 2004). Vegetables irrigated with wastewater coupled with application of chemical fertilizers and pesticides and use of chicken manures have been reported to be a source of heavy metals in food chain (Modaihsh et al., 2004). The heavy metal contaminated soil due to agricultural activities has raised serious issue of potential threat to human health through the direct intake, bio accumulation in food chain and hazardous effect on complete ecosystem. Metal polluted soils have been observed to have a negative effect on physiological activities of plants (e.g. photosynthesis, gaseous exchange and nutrient absorption) resulting in reduction of plant growth, dry matter accumulation and yield (Suciu et al., 2008). Thus, higher concentration of heavy metals in agricultural soils enhances their uptake by crops which affect the quality of food. The available heavy metals in the soil get accumulated in the vegetation by the natural process of bioaccumulation (Chao et al., 2007). Moreover, presence of heavy metals in soils, reduce the bio degradation process of organic pollutants as well, leading to greater environment pollution. The common heavy metals found in contaminated soils are $\mathrm{Pb}, \mathrm{Cr}$, $\mathrm{As}, \mathrm{Zn}, \mathrm{Cd}, \mathrm{Cu}$, and $\mathrm{Hg}$ which bear potential capability to decrease crop production, risk of bioaccumulation and groundwater contamination. Thus long term accumulation of these metals in soil results in translocation of metals from soil to the vegetables through root uptake. The toxic metal concentration can reduce soil fertility and lead to accumulation of toxic metals in food stuffs to cause potential health issues to the consumers 
(Khan et al., 2008). Also, one of the causes of increased neurological problems is due to the consumption of food and vegetables contaminated with heavy metals (Duruibe et al., 2007).

\section{Remediation of heavy metal contaminated soils}

\section{Physical methods}

\section{Soil replacement}

This is an age old remediation technique in which contaminated soil is replaced by new soil. In this method contaminants are replaced fully or partially by excavating contaminated soil and its replacement by non-contaminated soil. This method enhances the soil functionality by lowering the concentration of heavy metals in the soil matrix (Yao et al., 2012,). However, this technique is limited to very small areas due to involvement of high cost and only used when soil is heavily contaminated posing high risk to environment. Despite being expensive, another major challenge with this technique lies with the necessity to treat the contaminated soil removed in order to avoid secondary pollution. So, the replaced soil usually undergoes treatment to remove heavy metals. Replacing contaminated soil can be done by soil spading, which allows the heavy metals to settle in deeper layers or importing new uncontaminated soil. In soil spading, contaminated site is dug deep and the heavy metals are spread into these deep sites, hence lowering metal concentrations in upper soil surface. In second method, uncontaminated soil is added either on the surface or mixed into the heavy metals polluted soil to reduce concentration of metals in soil. Advantages of soil replacement/ excavation include the rapid cleanup of contaminated site with the complete removal of contaminants (Wood, 1997). However, there could be a risk of pollution at the site where contaminated soil is moved, therefore it should first undergo pre-treatment process to avoid the risk of spreading any further contamination.

\section{Soil isolation}

Soil isolation prevents the movement of heavy metals and other contaminants from the contaminated site by restricting them within a specific area in order to avoid any further contamination of groundwater by heavy metals (Zhu et al., 2012). In this technology subsurface barriers like slurry walls and sheet piles are commonly used to separate the contaminated soil and water by restricting the flow of ground and/or surface water at the contaminated site. Vertical barriers are installed downstream, upstream, or completely surrounding the site, mostly in combination with a capping system to restrict the infiltration of uncontaminated surface water. However, these barriers cannot be installed to deep soil and are often limited to around $30 \mathrm{ft}$. Vertical subsurface barriers restrict the lateral movement of groundwater.

\section{Vitrification}

Vitrification is the process of heating the soil to an approximate temperature of about 1700 $2000{ }^{\circ} \mathrm{C}$, where soil matrix melts and later freezes to solid, glass-like material. This glass-like solid mass is known as vitrified product which immobilizes waste constituents within the matrix, thereby isolating them from the environment. Due to high temperature, the organic contaminants are destroyed or volatilized which could be collected for disposal or further treatment. Vitrification can be done ex/ in-situ depending on the situation, however, in-situ technique is preferred due to lower cost involved. The process of in-situ vitrification requires the use of electrodes which are installed vertically into the contaminated soil and electric current is 
passed through the soil. In case of dry soils, to provide enough conductance, a trench containing ground glass particles could be placed between the electrodes to provide an initial flow of current. Melting of soil outward and down due to heating provides additional conductance for the current. A single melt can treat up to 1000 tons of contaminated soil up to a depth of twenty feet. The main requirement for in-situ vitrification is the ability of the soil melt to carry current and solidify as it cools. This glass-like material has low leachability and the vitrified waste may be recycled to be used as clean fill or other reusable materials [Smith et al., 1995]. In Japan, this method was used to reduce the radioactive wastes produced from its nuclear plants. Vitrification coupled with certain soil amendments viz., fly ash, activated carbon etc. helps to increase immobilization/ stabilization efficiency to almost $96 \%$ at $1200^{\circ} \mathrm{C}$ (Mallampati et al., 2015).

\section{Electrokinetics}

Another technology for removal of heavy metals is electroremediation, which involves the electro-kinetic movement of charged particles suspended in soil solution, initiated by an electric gradient (Seyed et al., 2012). Electrokinetic remediation is an in-situ remediation technique that is often used to remediate soils having low-permeability [Tong et al., 2012]. It is utilized for the removal of contaminants from soil, sediments and sludge. In this process, direct electric current of low intensity is applied to the porous matrix which needs to be decontaminated. The effect of the electric field induces the mobility and transport of heavy metals through the porous matrix towards anode and cathode where they are collected, pumped out and treated. The electrodes are inserted into the soil inside a chamber which is filled with water or appropriate solution to accelerate the removal of contaminants. Typically, a voltage drop of $1 \mathrm{VDC} / \mathrm{cm}$ is applied to the main electrodes. Contaminants are transported out of the soil due several transportation mechanisms induced by the electric field (Acar et al., 1990). Electro kinetic remediation involves three main processes: electroosmosis, electrophoresis and electrolytic migration of ionic species.

Electro osmosis produces quick flow of water in less permeable soils and is very useful especially in removing contaminants from the clay soils. This process depends on the properties of the solid surface, interstitial fluid and interaction between the solid surface and the components of the solution.

Electromigration is the transport of ions towards the oppositely charge electrodes in solution in the interstitial fluid of the soil matrix. Anions move towards positive electrode anode and cations move towards negative electrode cathode. The ionic migration is affected by the size and charge of the ion and strength of electric field.

Electrophoresis is the movement of the charged colloids in the soil-liquid mixture. In a compact system, electrophoresis is of less significance since the solid phase is restricted from the movement.

\section{Chemical methods}

\section{Immobilization techniques}

This is the most widely used technique to slow down the transport and availability of heavy metals in contaminated soils by addition of organic/ inorganic immobilizing materials like compost, clay, cement, phosphate fertilizers, redmud, fym, termitaria and zeolites etc., Immobilization techniques could be carried out both ex-situ and infield conditions to remediate metal-contaminated 
soils. In-situ immobilization techniques are more preferred because of low costs involved (Wuana and Okieimen, 2011). This technique involves the in -field fixation of heavy metals by applying chemical amendments to the soil that facilitate the formation of complexes containing heavy metals in a form which is not easily accessible or absorbed by plants. Recently, low-cost industrial residues like red mud (Lombi et al., 2002) and termitaria are also being used to immobilize the heavy metals in soils. The main function of immobilizing materials is the alteration of metals to less toxic and stable forms through various reactions like precipitation, chemical adsorption, ion exchange, formation of stable complexes with organic ligands and redox reactions etc., (Wang et al., 2009). This process allows heavy metals to remain in the soil without causing much harmful effect to environment. However, if the soils are heavily contaminated with metals and it is of greater concern to the environment, than ex-situ technique is preferred and the soil is removed from the original place. In-situ method of immobilization offers advantages of being inexpensive, simple, rapid and highly accepted due to ease of operation. Nowadays, organic amendments are gaining attention for immobilizing heavy metals in soils and are widely advocated, as these tend to change highly bioavailable forms i.e. free metals to much less available fractions associated with organic matter, metal oxides or carbonates (Walker et al., 2004). Since organic amendments release humic acids, which very well bind with different heavy metals including $\mathrm{Cd}, \mathrm{Cr}, \mathrm{Cu}$, and $\mathrm{Pb}$ and tend to immobilize heavy metals in soil (Walker et al., 2004). In a research by Liu et al.,(2009) they revealed that application of compost effectively reduced cadmium uptake in wheat by more than $50 \%$, thus improving wheat growth. Metals are known to form soluble and insoluble complexes with organic component in soils (Shahid et al., 2014e) called as metal- organic matter complexes. Due to the presence of functional groups viz., carbonyl, phenolic, amino, amido groups, structural polysaccharides and esters in FYM, its incorporation in soil has proved to be highly effective in immobilizing $\mathrm{Fe}, \mathrm{Cr}, \mathrm{Ni}, \mathrm{Mn}$, and $\mathrm{Pb}$ because of metal complexation with organic matter (Niazi et al., 2016a). Phosphorus containing amendments have commonly been used for in situ remediation of metal contaminated soils (Hong et al., 2010). Most phosphate compounds are used to immobilize metals such as $\mathrm{Cd}, \mathrm{Cu}, \mathrm{Pb}$, and $\mathrm{Zn}$ by reducing their bioavailability (Bolan $e t$ al., 2014). Also, recent studies have shown that red mud has great potential for immobilization of a range of heavy metals such as $\mathrm{Cd}, \mathrm{Cu}, \mathrm{Ni}, \mathrm{Pb}$ and $\mathrm{Zn}$ in mine tailings (Valerie 2015). Moreover, use of biochar as a soil amendment has been receiving significant attention to immobilize heavy metals in the soil. Immobilization techniques reduce the ability of heavy metals to adversely affect human health and the ecology.

\section{Soil washing}

This process can be implemented in field/ exsitu which involves physical and/or chemical procedures to extract heavy metals from the soil. It involves the reduction/ removal of heavy metals from the soil using various chemical reagents and extractants such as EDTA, organic acids, humic substances, surfactants and cyclodextrins etc., which can leach down the heavy metals in soil (Kulikowska et al., 2015). Soil washing can be carried out as physical separation of highly contaminated soil particles from the bulk soil fractions or contaminants in soil could be removed by chemicals extraction [Dermont $e t$ al., 2008]. Once the contaminants are separated, they could be further treated with chemical, thermal or biological methods before dumping into landfills. With the use of chemical extractants, contaminants on soil 
particles are transferred into solution. Since, heavy metals are sparingly soluble in water and occur predominantly in asorbed state, therefore usage of water alone in soil washing can possibly result in removing very less amount of metals [Davis and Singh, 1995]. Hence, strong aqueous solutions of acids, alkalis and surfactants etc., are used to clean soil particles and these are then separated from the resulting solution. This solution is then treated to remove the contaminants by sorption on activated carbon or ion exchange. The eff ectiveness of soil washing is closely related to the ability of the extracting solution to dissolve the metal contaminants in soil. Therefore, only extractants capable of dissolving large quantities of metals would be suitable for cleaning purposes. Soil washing involves soil flushing that is an in-situ process in which the washing solution is forced through the soil matrix while ex-situ extraction of heavy metal occurs from the soil slurry in reactors and soil heap leaching. During ex-situ process, the contaminated soil is dug out and mixed with a suitably chosen extractant solution depending on the type of metal to be extracted and physio-chemical properties of the soil. The extractant solution and soil are mixed thoroughly for a specific time. Through the chemical reactions such as precipitation, ions exchange, chelation and adsorption etc., the heavy metals in the soil are transferred from soil to liquid phase and thereafter separated from leachate (Ferraro et al., 2015). The separated soil which fulfills the regulatory criteria can be backfilled to original site. Soil washing is frequently used for the remediation of contaminated sites because it completely removes the metals from the soil. Moreover, soil washing is a rapid method which can meet specific criteria without any long-term liability (Parkandson, 2016) owing to its high efficiency and is one of the most cost-effective soil remediation technologies.

\section{Biological methods}

\section{Bio remediation}

Bioremediation is mostly applicable to those sites which are contaminated with organic pollutants. It is a viable option to rectify and re-establish the natural condition of metal contaminated soils. Bioremediation makes use of microorganisms and/ plants to detoxify or remove heavy metals from the soil. This method is cost-effective and non-invasive in nature. However, many researchers have suggested that bioremediation has limited scope to remediate metal-polluted environments since heavy metals cannot undergo degradation (Marschner, 1995).

\section{Microbial bioremediation}

Use of micro- organisms (that utilize contaminants as a source of food and energy) to clean up contaminated soil and groundwater is called as microbial remediation. The microorganisms cannot degrade or destroy the heavy metals but can affect the migration and transformation by changing their physical and chemical characterizations. Bacterial strains like Bacillus subtilis have been used for reduction of $\mathrm{Cr}$ (VI) to the less toxic $\mathrm{Cr}$ (III) and other non metallic elements. For instance, Garbisu et al., (2001) reported that B. subtilis reduced the selenite to less toxic elemental Se. Also, B.cereus and $B$. thuringiensis have been shown to increase extraction of $\mathrm{Cd}$ and $\mathrm{Zn}$ from $\mathrm{Cd}$ rich soil and soil polluted with effluent from metal industry.

\section{Phytoremediation}

Over the past decade, there has been an increasing interest for the development of plant based remediation technologies which bear the potential to be low-cost, effective and environmentally sound (Cunningham and $\mathrm{Ow}$, 
1996). Phytoremediation uses various types of plants to remove, transfer, stabilize and destroy the contaminants in soil \& ground water. Toxic heavy metals and organic pollutants are the major targets of phytoremediation. It has been reported that plants were used for the treatment of waste water over 300 years ago (Hartman, 1975). This technology is gaining attention due to cost-effectiveness and eco- friendly approach. Hyper-accumulators, are good candidates in phytoremediation, particularly for the removal of heavy metals. Genetic engineering techniques are also being used to improve the process of phytoremediation. The efficiency of phytoremediation can be substantially improved using various chemicals which help enhancing the mobility of heavy metals in soils and thus increase their uptake by plants. This is based upon several processes such as phytoaccumulation,

phytoextraction, phytodegradation and phytovolatilization, etc., as described below:

\section{Phyto-stabilization}

Phytostabilization is the process of limiting the mobility and bioavailability of contaminants in the soil using plant roots. It is also called as in-place inactivation, and is primarily used for the remediation of soil, sediment, and sludges (United States Protection Agency, 2000). In this process, chemical compounds are being produced by the plant roots which immobilize contaminants in the soil or contaminants are being absorbed \& accumulated in roots or precipitated in the rhizosphere. This technique reduces the mobility of contaminants preventing their transport into the groundwater and is useful for the cleanup of $\mathrm{Cr}, \mathrm{Cu}, \mathrm{As}, \mathrm{Cd}, \mathrm{Pb}$ and $\mathrm{Zn}$. In a greenhouse experiment on phytostabilization conducted by Jadia and Fulekar (2009), they used sorghum plants to remediate heavy metal contaminated soil and reported that growth of sorghum plants was adversely affected by heavy metals at higher concentrations of 40 and $50 \mathrm{ppm}$, while lower concentrations (5 to 20 ppm) stimulated shoot growth and increased plant biomass. Further, heavy metals were efficiently taken up mainly by roots of sorghum plant at all the evaluated concentrations of 5,10, 20, 40 and $50 \mathrm{ppm}$. The plant uptake of heavy metals was in decreasing order of $-\mathrm{Zn}>\mathrm{Cu}>\mathrm{Cd}>\mathrm{Ni}>\mathrm{Pb}$.

\section{Phyto-extraction}

In this process, plant roots absorb the contaminants along with water and other nutrients. Removal of contaminants from the environment by accumulating them in aboveground plant parts is called phytoextraction. This process is also known as phytoaccumulation. Plants absorb contaminants through the passage of roots and store them in the tissues of stems or leaves. Hyperaccumulators are the plants species capable of accumulating heavy metals in their shoot tissues to the levels far above those present in the soil or in non-accumulating plant species (Ali et al., 2013). The contaminants might not be necessarily degraded but are removed from the environment post harvest of plants. Salt et al., (1995a) reported that the cost involved in phytoextraction would be more than ten times less per hectare compared to conventional soil remediation techniques.

\section{Rhizosphere biodegradation}

In this process, both terrestrial and aquatic plants are used to absorb, concentrate, and precipitate the contaminants in their roots. This process is used to decontaminate groundwater. Plants are first grown in greenhouses in water instead of soil medium. Contaminated water from the site is used to acclimatize the plants to the environment. The plants are then transplanted on the site of 
contaminated groundwater where roots take up the water and contaminants. Once the roots are saturated with the contaminants, the plants are harvested including the roots. Heavy metals like $\mathrm{Pb}, \mathrm{Cd}, \mathrm{Cu}, \mathrm{Ni}, \mathrm{Zn}$ and $\mathrm{Cr}$ can be extracted using rhizofiltration. In an experiment by Dushenkov et al., (1995), they revealed that roots of many hydroponically grown terrestrial plants such as Indian mustard and sunflower effectively removed the toxic metals such as $\mathrm{Cu}, \mathrm{Cd}, \mathrm{Cr}, \mathrm{Ni}, \mathrm{Pb}$ and $\mathrm{Zn}$, from aqueous solutions.

Table.1 Sources of heavy metals in India (CPCB 2009)

\begin{tabular}{|c|c|}
\hline Metal & Industry \\
\hline Copper $(\mathbf{C u})$ & Smelting, mining, electroplating, sulphuric acid plant. \\
\hline Nickel (Ni) & Battery industry, smelting, thermal power plants. \\
\hline Arsenic (As) & $\begin{array}{l}\text { Thermal power plants, pesticides, fungicides, geogenic/natural processes, } \\
\text { smelting operations, fuel burning. }\end{array}$ \\
\hline Mercury (Hg) & $\begin{array}{l}\text { Fluorescent lamps, hospital waste, thermal power plants, paper industry, } \\
\text { electrical appliances. }\end{array}$ \\
\hline $\begin{array}{l}\text { Chromium } \\
\text { (Cr) }\end{array}$ & $\begin{array}{l}\text { Chromium salts manufacturing, leather tanning, mining, industrial } \\
\text { coolants. }\end{array}$ \\
\hline Lead $(\mathbf{P b})$ & $\begin{array}{l}\text { Lead batteries, paints, smelting, coal- based thermal power plants, } \\
\text { ceramics, bangle industry. }\end{array}$ \\
\hline Cadmium (Cd) & Zinc smelting, pesticides, fertilizers, waste batteries, fuel combustion. \\
\hline Zinc (Zn) & Brass manufacturing, smelting, electroplating. \\
\hline Mangnese(Mn) & Welding, Ferro mangnese production. \\
\hline
\end{tabular}

Table.2 Agricultural sources of heavy metal contamination in soils $\left(\mathrm{mg} \mathrm{kg}^{-1}\right)$

(Pendias and Pendias, 2000)

\begin{tabular}{|l|c|c|c|c|c|}
\hline Element & $\begin{array}{c}\text { Nitrogenous } \\
\text { fertilizers }\end{array}$ & $\begin{array}{c}\text { Phosphate } \\
\text { fertilizers }\end{array}$ & Manures & Pesticides & $\begin{array}{c}\text { Sewage } \\
\text { sludge }\end{array}$ \\
\hline Arsenic & $2-120$ & $2-1200$ & $3-150$ & $22-60$ & $2-26$ \\
\hline Copper & $1-15$ & $1-300$ & $2-60$ & $12-50$ & $50-3300$ \\
\hline Chromium & $3-19$ & $66-245$ & $5.2-55$ & - & $20-40600$ \\
\hline Cadmium & $0.05-8.5$ & $0.1-170$ & $0.3-0.8$ & - & $2-1500$ \\
\hline Nickel & $7-38$ & $7-38$ & $7.8-30$ & - & $16-5300$ \\
\hline Lead & $2-1450$ & $7-225$ & $6.6-15$ & 60 & $50-3000$ \\
\hline Mercury & $0.3-3$ & $0.01-1.2$ & $0.09-26$ & $0.8-42$ & $0.1-55$ \\
\hline Zinc & $1-42$ & $50-1450$ & $15-250$ & $1.3-25$ & $700-49000$ \\
\hline
\end{tabular}


Table.3 Comparison of heavy metal remediation technologies

\begin{tabular}{|c|c|c|c|}
\hline Techniques & Process & Pros & Cons \\
\hline $\begin{array}{l}\text { Physical } \\
\text { remediation } \\
\text { Soil replacement }\end{array}$ & $\begin{array}{l}\text { Original contaminated soil is } \\
\text { replaced by non-contaminated soil }\end{array}$ & $\begin{array}{l}\text { Very useful in } \\
\text { heavily } \\
\text { contaminated soils. }\end{array}$ & $\begin{array}{l}\text { Costly, limited to small areas, } \\
\text { excavated soil if not given pre } \\
\text { treatment than chances of } \\
\text { secondary pollution }\end{array}$ \\
\hline Soil isolation & $\begin{array}{l}\text { Use of subsurface barriers to } \\
\text { isolate contaminated soil from the } \\
\text { uncontaminated soil }\end{array}$ & $\begin{array}{l}\text { Useful for highly } \\
\text { contaminated soils, } \\
\text { Prevent off-site } \\
\text { movement of heavy } \\
\text { metals. }\end{array}$ & $\begin{array}{l}\text { High cost, Effectiveness of this } \\
\text { method depends on the type of } \\
\text { subsurface barrier used. }\end{array}$ \\
\hline Vitrification & $\begin{array}{l}\text { Soil is melted at high temperature } \\
\text { to form vitrified product } \\
\text { containing contaminants }\end{array}$ & $\begin{array}{l}\text { Can be applied to } \\
\text { variety of } \\
\text { contaminants, Ease } \\
\text { of application. }\end{array}$ & $\begin{array}{l}\text { High energy requirement } \\
\text { increases cost }\end{array}$ \\
\hline $\begin{array}{l}\text { Electrokinetic } \\
\text { remediation }\end{array}$ & $\begin{array}{l}\text { Heavy metals are removed from } \\
\text { soil via electrophoresis, electro- } \\
\text { migration by applying DC-voltage }\end{array}$ & $\begin{array}{l}\text { Cost effective, Ease } \\
\text { of application. }\end{array}$ & $\begin{array}{l}\text { Limited to low permeability soils/ } \\
\text { clay soil, pH needs to be } \\
\text { controlled }\end{array}$ \\
\hline $\begin{array}{l}\text { Chemical } \\
\text { remediation } \\
\text { Immobilization }\end{array}$ & $\begin{array}{l}\text { Soil application of immobilizing } \\
\text { amendments to reduce metal } \\
\text { mobility and availability by } \\
\text { formation of metal complex } \\
\text { through adsorption, precipitation } \\
\text { reactions etc. }\end{array}$ & $\begin{array}{l}\text { Rapid and easy, } \\
\text { Low cost, Covers a } \\
\text { large spectrum of } \\
\text { inorganic pollutants }\end{array}$ & $\begin{array}{l}\text { It provides temporary solution } \\
\text { and regular monitoring is advised }\end{array}$ \\
\hline Soil washing & $\begin{array}{l}\text { Use of chemical extractants to } \\
\text { remove heavy metals from soil } \\
\text { and forming stable and mobile } \\
\text { complexes }\end{array}$ & $\begin{array}{l}\text { Complete removal } \\
\text { of metals, Cost- } \\
\text { effective }\end{array}$ & $\begin{array}{l}\text { Effectiveness varies with soil } \\
\text { type, extractant type and metal to } \\
\text { be extracted, Chemical } \\
\text { extractants could cause } \\
\text { environmental pollution. }\end{array}$ \\
\hline $\begin{array}{l}\text { Biological } \\
\text { remediation } \\
\text { Phyto- } \\
\text { volatilization }\end{array}$ & $\begin{array}{l}\text { Heavy metal are absorbed from } \\
\text { soil through roots and released by } \\
\text { stem/ leaves in vapour form. }\end{array}$ & $\begin{array}{l}\text { Cost effective, less } \\
\text { harmful. }\end{array}$ & $\begin{array}{l}\text { Limited to volatile metals like } \\
\text { mercury, Could cause air } \\
\text { pollution due to release of metal } \\
\text { in atmosphere }\end{array}$ \\
\hline $\begin{array}{l}\text { Phyto- } \\
\text { stabilization }\end{array}$ & $\begin{array}{l}\text { Mobility and availability of metals } \\
\text { is decreased using green plants via } \\
\text { sequestration in plant roots. }\end{array}$ & Economical. & $\begin{array}{l}\text { It is not a permanent solution. } \\
\text { Effectiveness of method depends } \\
\text { on soil, plant and metal type. }\end{array}$ \\
\hline Phytoextraction & $\begin{array}{l}\text { Hyperaccumulator plants are used } \\
\text { to absorb, translocate, and } \\
\text { concentrate heavy metals from } \\
\text { soil to aboveground plant parts. }\end{array}$ & $\begin{array}{l}\text { Highly economical, } \\
\text { less disruptive. }\end{array}$ & $\begin{array}{l}\text { Post harvest, there could be } \\
\text { problem in disposal of plants. } \\
\text { This process depends on } \\
\text { tolerance of the plant and } \\
\text { bioavailability of metals in soil. }\end{array}$ \\
\hline $\begin{array}{l}\text { Phyto- } \\
\text { degradation }\end{array}$ & $\begin{array}{l}\text { Plants metabolize and destroy the } \\
\text { contaminants within plant tissues. }\end{array}$ & Highly economical & $\begin{array}{l}\text { After harvest, there could be } \\
\text { problem in disposal of plants. }\end{array}$ \\
\hline
\end{tabular}


Figure.1 Sources of heavy metals \& cycle of metal translocation from soil to organism

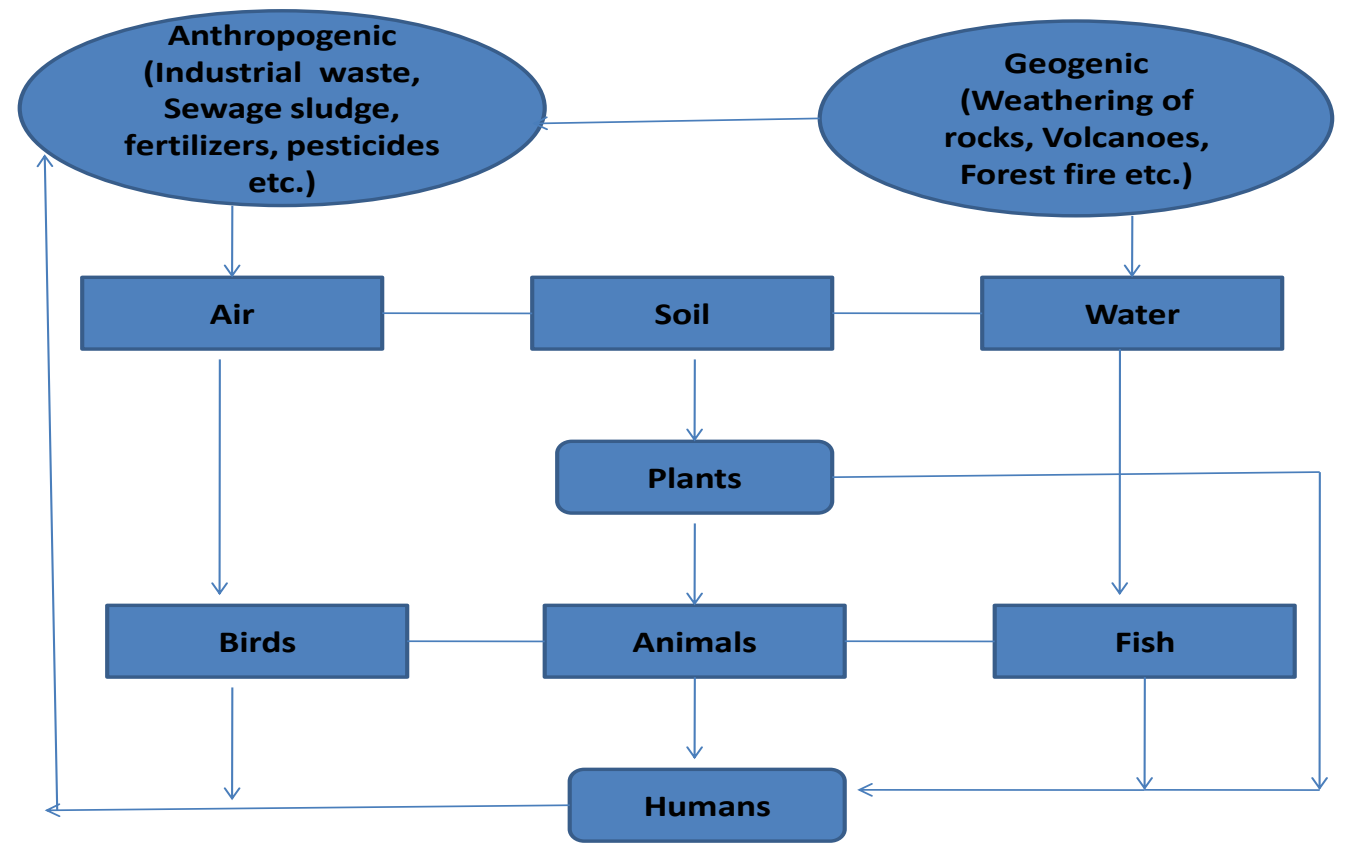

\section{Phyto-volatilization}

In this process, plants take up water containing organic contaminants and release the contaminants into the air through their leaves. Plants absorb contaminants from the soil into stems or leaves and thereafter transform them into volatile compounds which get transpired into the atmosphere (United States Protection Agency, 2000). Mercuric mercury metal contaminant is mainly being removed by the process of phyto-volatilization. In laboratory experiments, tobacco ( $N$. tabacum) and a small model plant (Arabidopsis thaliana) that had been genetically modified to include a gene for mercuric reductase converted ionic mercury $(\mathrm{Hg}(\mathrm{II}))$ to the less toxic metallic mercury $(\mathrm{Hg}(0))$ and volatilized it (Meagher et al., 2000).

Hence, concluded in today's scenario, it is important to study and understand the extent of pollution caused by heavy metals especially in agricultural soils that act as a direct link in translocation of metals to plant parts and hence bio-accumulate in food chain. Heavy metals pose a great risk to humans, animals and plant health and therefore remediation of metal contaminated soils is of utmost importance. Plants growing on heavy metal polluted soils show a reduction in growth due to changes in their physiological and biochemical activities. Various techniques like immobilization, soil washing and phytoremediation have proved to be best technologies for cleaning up heavy metal contaminated soils in developed countries. Also, organic amendments such as farmyard manure, biochar and vermicompost have been observed to bring reduction in translocation of metals from soil to plants. Combining both plants and microorganisms in bioremediation, increases the efficiency of remediation methods. The success of the combined use of these organisms depends on the species of microbe and plants involved and to some extent on the concentration of the heavy 
metals in soil. To make the remediation measures more effective, combined application of various amendments needs to be tested to remove / reduce heavy metal concentrations in soils. Experiments should be conducted to develop cost effective and environment friendly technology with long lasting benefits of remediation. A strong policy should be initiated to the contaminated water discharging units as well as its consumers. A wide awareness campaign should be started with the help of the government agencies or non government organizations (NGOs) regarding the heavy metal toxicity and its consequences with farmers and Industry entrepreneurs.

\section{References}

Acar YB, Gale RJ, Putnam GA, Hamed J, Wong RL. Electrochemical processing of soils: Theory of $\mathrm{pH}$ gradient development by diffusion, migration, and linear convection. Journal of Environmental Science and Health Part A Environmental Science and Engineering 1990;25(6):687-714.

Acar YB. Principles of electrokinetic remediation. Environment Science Technology 1993;27(13):2638-2647.

Adriano, D. C., Trace Elements in Terrestrial Environments:

Biogeochemistry, Bioavailability and Risks of Metals, Springer, New York, NY, USA, 2nd edition, 2003.

Alloway BJ (1995) Heavy metals in soils, 2nd ed. Blackie Academic and Professional, London

Anoduadi, C. O., L.B. Okenwa, F. E. Okieimen, A. T. Tyowua, and E.G.U wumarongie -Ilori, "Metal immobilization in CCA contaminated soil using laterite and termite mound soil. Evaluation by chemical fraction at ion," Nigerian Journal of Applied Science, vol. 27, pp. 77-87, 2009.
Athar M, Vohora SB. Heavy Metals and Environment. New Delhi: New Age International (P) Limited; 2001

Basta, N. T., J. A. Ryan, and R. L. Chaney, "Trace element chemistry in residualtreated soil: key concepts and metal bioavailability". Journal of Environmental Quality, vol. 34,no. 1, pp. 49-63, 2005.

Boisson, J., M. Mench, J. Vangronsveld, A. Ruttens, P. Kopponen, and T. De Koe, "Immobilization of trace metals and arsenic by different soil additives: evaluation by means of chemical extractions," Communications in Soil Science and Plant Analysis, vol. 30, no. 3-4, pp. 365-387, 1999.

Chaney, R. L. and D. P. Oliver, "Sources, potential adverse effects and remediation of agricultural soil contaminants," in Contaminants and the Soil Environments in the Australia Pacific Region, R. Naidu, Ed., pp. 323359, Kluwer Academic Publishers, Dordrecht, The Netherlands, 1996.

CLAIRE, "Understanding soil washing, contaminated land: applications in real environments," Tech. Rep. TB13, 2007.

Cunningham, S. D. and D. W. Ow, "Promises and prospects of phytoremediation," Plant Physiology, vol. 110, no. 3, pp. 715-719, 1996.

D'Amore, J. J., S. R. Al-Abed, K. G. Scheckel, and J. A. Ryan, "Methods for speciation of metals in soils: a review," Journal of Environmental Quality, vol.34, no.5, pp.1707-1745, 2005.

Sumner, M. E., "Beneficial use of effluents, wastes, and biosolids," Communications in Soil Science and Plant Analysis, vol. 31, no. 11-14, pp. 1701-1715, 2000.

Davis, P.and I. Singh, "Washing of zinc(II) from contaminated soil column," Journal of Environmental Engineering, vol. 121, no. 2, pp. 174-185, 1995. 
Dermont, G., M. Bergeron, G. Mercier, and M. Richer Lafl`eche, "Soil washing for metal removal: a review of physical/chemical technologies and field applications," Journal of Hazardous Materials, vol. 152, no. 1, pp. 1-31, 2008.

Garbisu, C. and I. Alkorta, Phytoextraction: a cost-effective plant-based technology for the removal of metals from the environment. Bioresource Technology, vol.77, no.3, pp. 229-236, 2001.

Gingell, R., Wallcave, L., Nagel, D., Kupper, R., and Pour, P. (1976). Metabolism of the pancreatic carcinogens $\mathrm{N}$-nitrosobis (2-oxopropyl) amine and N-nitrosobis (2-hydroxypropyl) amine in the Syrian hamster. J. Natl. Cancer Inst. 57, 1175-1178.

GWRTAC, "Remediation of metalscontaminated soils and groundwater," Tech. Rep. TE-97-01, GWRTAC, Pittsburgh, Pa, USA, 1997, GWRTACE Series.

Hashimoto, Y., H. Matsufuru, M. Takaoka, H. Tanida, and T. Sato, "Impacts of chemical amendment and plant growth on lead speciation and enzyme activities in a shooting range soil: an $\mathrm{X}$ ray absorption fine structure investigation," Journal of Environmental Quality, vol. 38, no. 4, pp. 1420-1428, 2009.

Jadia, C. D. and M. H. Fulekar, "Phytoremediation of heavy metals: recent techniques," African Journal of Biotechnology, vol. 8, no. 6, pp. 921928, 2009.

Kabata-Pendias, A. and H. Pendias, Trace Metals in Soils and Plants, CRC Press, Boca Raton, Fla, USA, 2nd edition, 2001.

Khan, S., Q. Cao, Y. M. Zheng, Y. Z. Huang, and Y. G. Zhu, "Health risks of heavy metals in contaminated soils and food crops irrigated with wastewater in
Beijing, China," Environmental Pollution, vol. 152, no. 3, pp. 686-692, 2008.

Kiekens L. (1995): Zinc. In: Alloway B.J. (ed.): Heavy Metals in Soils. Chapman \& Hall, London, 284-303.

Kirpichtchikova, T. A., A. Manceau, L. Spadini, F. Panfili, M. A.Marcus, and T. Jacquet, "Speciation and solubility of heavy metals in contaminated soil using X-ray micro fluorescence, EXAFS spectroscopy, chemical extraction, and thermodynamic modeling," Geochimica et Cosmochimica Acta, vol. 70, no. 9, pp. 2163-2190, 2006.

Lepp NW. Effect of heavy metal pollution on plants. Metals in the Environment, Pollution Monitoring Series, Applied Science Publishers. Department of Biology. Liverpool, United Kingdom: Liverpool Polytechnic; 2012;2

Lin, Y. F., and Aarts, M. G. (2012). The molecular mechanism of zinc and cadmium stress response in plants. Cell. Mol. Life Sci. 69, 3187-3206. doi: 10.1007/s00018-012-1089-z

Ling, W., Q. Shen, Y. Gao, X. Gu, and Z. Yang, "Use of bentonite to control the release of copper from contaminated soils," Australian Journal of Soil Research, vol. 45, no. 8, pp. 618-623, 2007.

Lombi, E., F.J. Zhao, G. Zhang et al., "Insitu fixation of metals in soils using bauxite residue: chemical assessment, "Environmental Pollution, vol. 118, no. 3, pp. 435-443, 2002.

Maslin, P. and R. M. Maier, "Rhamnolipidenhanced mineralization of phenanthrene in organic-metal cocontaminated soils," Bioremediation Journal, vol. 4, no. 4, pp. 295-308, 2000.

McGrath, S.P., A.M. Chaudri and K.E. Giller, 1995. Long-term effects of metals in sewage sludge on soils, microorganisms 
and plants. J. Indian Microbiol., 14: 94104.

McLaughlin, M. J., B. A. Zarcinas, D. P. Stevens, and N. Cook, "Soil testing for heavy metals," Communications in Soil Science and Plant Analysis, vol. 31,no. 11-14, pp. 1661-1700, 2000.

McLaughlin, M. J., R. E. Hamon, R. G. McLaren, T. W. Speir, and S. L. Rogers, "Review: a bioavailabilitybased rationale for controlling metal and metalloid contamination of agricultural land in Australia and New Zealand," Australian Journal of Soil Research, vol. 38, no. 6, pp. 10371086, 2000.

Musilova J, Arvay J, Vollmannova A, Toth T, Tomas J. Environmental contamination by heavy metals in region with previous mining activity. Bulletin of Environmental Contamination and Toxicology. 2016; 97: 569-57.

Pierzynski, G. M., J. T. Sims, and G. F. Vance, Soils and Environmental Quality, CRCPress, London, UK, $2^{\text {nd }}$ edition, 2000.

Seyed Razavi SN, Khodadadi A, Ganjidoust

H. Treatment of soil contaminated with crude-oil using biosurfactants. Journal of Environmental Studies 2012; 37(60): 107-116.

Smith, L. A., J. L. Means, A. Chen et al., Remedial Options for MetalsContaminated Sites, Lewis Publishers, Boca Raton, Fla, USA, 1995.
Tong M, Yuan S. Physiochemical technologies for $\mathrm{HCB}$ remediation and disposal: A review. J Hazard Mater 2012; 229-230: 1-14.

USEPA, "Vitrification technologies for treatment of Hazardous and radioactive waste handbook," Tech. Rep. EPA/ 625/R-92/002, United States Environmental Protection Agency, Office of Research and Development, Washington, DC, USA, 1992.

Wang, L. Q., L. Luo, Y. B Ma, D. P. Wei, and L. Hua, "In situ immobilization remediation of heavy metalscontaminated soils: a review," Chinese Journal of Applied Ecology, vol. 20, no. 5, pp. 1214-1222, 2009.

Wei B, Yang L (2010) A review of heavy metal contaminations in urban soils, urban road dusts and agricultural soils from China. Microchem J 94(2): 99107

Zhang, Z. Y. Liu, and H. Wang, "Use of single extraction methods to predict bioavailability of heavy metals in polluted soils to rice," Communications in Soil Science and Plant Analysis, vol. 41, no. 7, pp. 820-831, 2010.

Zhaoand, Q., J. J. Kaluarachchi, "Risk assessment at hazardous wastecontaminated sites with variability of population characteristics," Environment International, vol. 28, no. 1-2, pp. 41-53, 2002.

\section{How to cite this article:}

Dimple Kaparwan, N. S. Rana and Dhyani, B. P. 2020. Heavy Metals Toxicity in Agricultural Soils-Critical Review of Possible Sources, Influence on Soil Health and Remedial Measures to Remove, Reduce and Stabilize Contaminants in Soil. Int.J.Curr.Microbiol.App.Sci. 9(06): 1467-1482. doi: https://doi.org/10.20546/ijcmas.2020.906.182 